\title{
BIO DIVERSITY IN THE CLOUD FORESTS OF THE KNUCKLES RANGE
}

\author{
D.R.N.S. Rajapaksha' \& V.A.M.P.K. Samarawickrama² \\ 1 University of Peradeniya \\ 2 IUCN -The World Conservation Union
}

The Knuckles Mountain Range is situated in the Intermediate Zone between the latitudes $7^{0} 18^{1}-7^{\circ} 34^{1}$ and longitudes $80^{\circ} 41^{1}-80^{\circ} 55^{1}$ within a $915-1906 \mathrm{~m}$ elevation range in the Matale District. The slopes directly exposed to monsoon winds receive a high amount of rainfall $(2725-4470 \mathrm{~mm})$ per annum. Temperature in the area ranges between $25^{\circ} \mathrm{C}$ and $27^{\circ} \mathrm{C}$ at lower altitudes and $18^{\circ} \mathrm{C}-20^{\circ} \mathrm{C}$ at higher altitudes.

Data were collected in the two localities Nawanagala and Decnston Nature trail in the submontane and montane forests on the west facing slopes from 6 a.m. 106 p.m. on $17^{\text {th }}-18^{\text {th }}$ August 2002.

The trees are low in stature $(<10 \mathrm{~m})$, gnarled and covered with lichens, mosses and epiphytic ferns. These plants represent the life forms; trecs, shrubs, herbs, creepes/ lianas. Their dominant families are Myrtaccac (Syzygium sp.), Rutaceac (Toddalia sp.), Clusiaceae (Calophyllum sp.), Orchidaceae (Eria bicolour) and Liliaceac (Asparagus sp.). The total number of species observed exceed 35 .

The animal life is highly diveres too. The total number of species identified in study area was 124 with 67 bird species ( 9 endemic), 2 fish ( 1 endemic), 20 butterflics ( 2 endemic), 16 mammals ( 4 endemic), amphibians ( 6 endemic) and 19 reptiles.

The Nawanagala and Deenston nature trail are unique areas of island's bio cliversity heritage. There are more plant and animal species, especially amphibians yet to be identified. The area faces the threat of periodic fires triggered by people. Morcover, the Deenston nature trail expericness the problem of garbage. Thercfore, the bio diversity of this unique area has to be conserved for future generations.

Proceedings of the Eighth Annual Forestry and Environment Symposium 2002 of the Department of Forestry and Environmental Science, University of Sri Jayewardenepura, Sri Lanka 